\title{
HET RIJKSMUSEUM AAN ZEE: HEMELSE BEELDEN UIT OOST EN WEST
}

Tijdens de verbouwing van het Rijksmuseum stond gedurende drie jaar een flinke keuze uit de collectie Aziatische kunst opgesteld in het nieuwe CODAmuseum, gelegen in het hart van Apeldoorn. Deze opstelling was afgeleid van de totaal vernieuwde opstelling in de verbouwde Zuidvleugel (nu Philipsvleugel) van het Rijksmuseum en gaf een representatief beeld van de collectie als geheel.

Toen bekend werd dat het verblijf in Apeldoorn in september 2007 ten einde zou lopen en de verbouwing van het Rijksmuseum nog enkele jaren zou duren, gingen we op zoek naar een ander, tijdelijk verblijf, liefst in ons eigen land. In Nederland is er geen museum te vinden, dat op een zelfde, kunsthistorische, manier Aziatische kunst verzamelt. Er is dus geen voor de hand liggende plaats. Maar wellicht was het mogelijk om een onderdeel bij een andere museumcollectie aan te passen. Ook wanneer het slechts om een klein deel zou gaan, is het belangrijk dat daarmee de collectie zichtbaar blijft. Daarom zochten we naar een onderdak met een contrast, en dat is het geworden. Maar wel een contrast binnen een thema, namelijk het thema 'sculptuur'. Een groep Aziatische beelden uit het Rijksmuseum gaat zich mengen onder hedendaagse beelden in Scheveningen.

Het particuliere museum in Scheveningen, Beelden aan Zee, dat zich bezighoudt met moderne en hedendaagse sculptuur, werd aangezocht. De directeur, Jan Teeuwisse, was bekend met de collectie en direct enthousiast over het plan. $\mathrm{Na}$ enig overleg stelde hij een hele zaal ter beschikking, de portretof zuidzaal. Normaal is daar aan een wand steeds een serie portretkoppen te zien. Het museum is jong en heeft nog geen grote collectie, maar portretten vormen een sterk onderdeel. Elk jaar krijgt een beeldhouwer een opdracht een portret te maken van een Nederlander die in het nieuws is. Er is ook een kleine, donkere ruimte geschikt voor prenten en andere werken op papier, en dan is er de eerste, ruime, helder verlichte zaal, waar de grote, gezichtsbepalende exposities worden gehouden. Dit jaar zal de eerste daarvan 'Territorial Bodies' zijn, een overzicht van hedendaagse kunst uit Israël.

De keuze van een zestigtal grote en kleine Aziatische beelden is gemaakt door Jan Teeuwisse en Wim Quist, ondersteund door ondergetekende. Wim Quist is niet alleen de architect van het museum Beelden aan Zee, maar ook de ontwerper van de opstelling 'Hemelse beelden uit oost en west'. Zijn ontwerp contrasteert op toepasselijke wijze met vroegere opstellingen van de Aziatische kunst. Om iets van hun oorspronkelijke plaatsing weer te geven, werden ze in het museum steeds tegen een wand tentoongesteld. De meeste Aziatische beelden zijn immers afkomstig uit verschillende soorten heiligdommen waar ze in tempelnissen stonden, of direct uit de grotwande access 


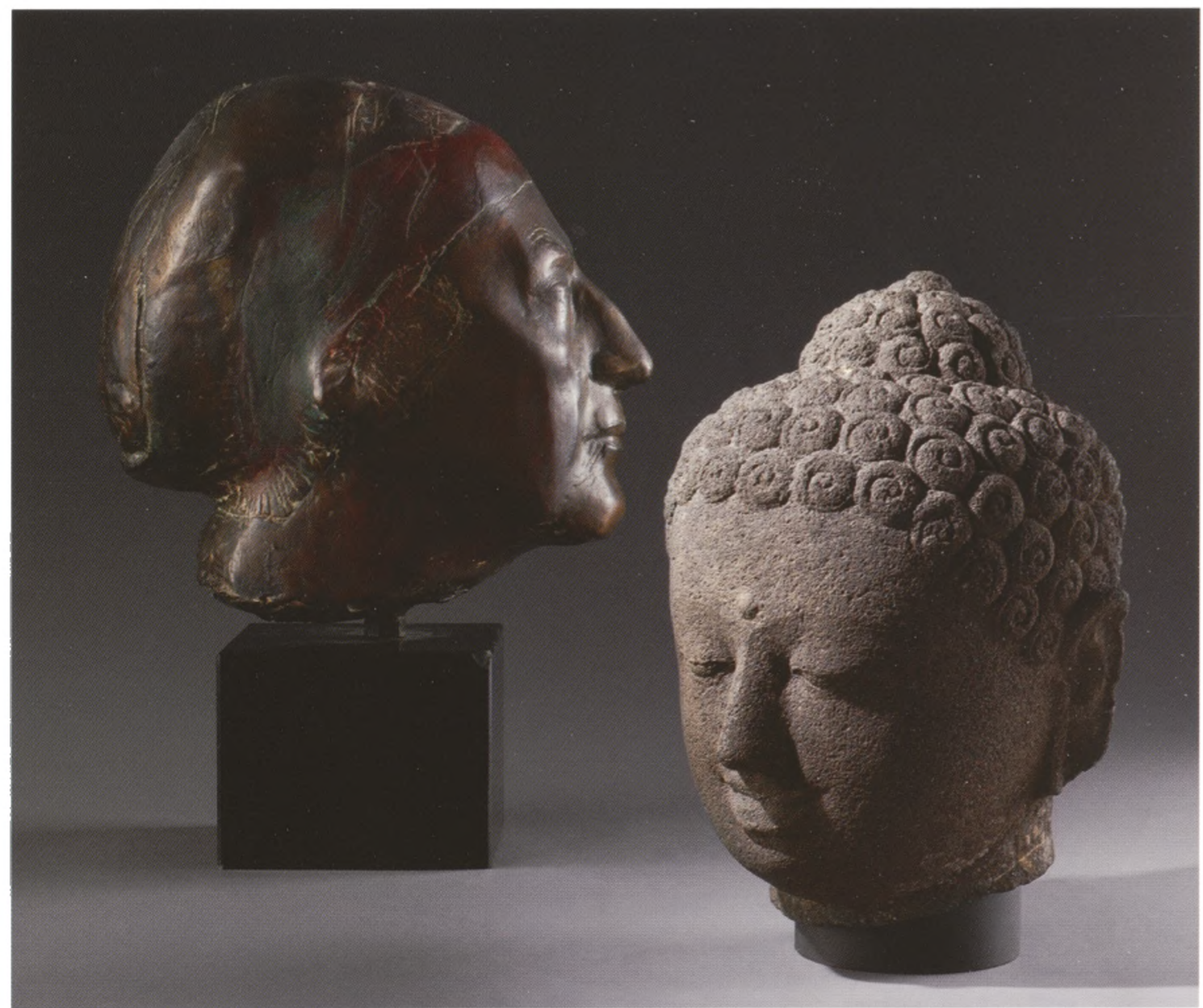

Kop van Brita door

Fioen Blaisse met

Boeddhakop van de

Boroboedoer,

Rijksmuseum, VVAK,

AK-MAK-239. Foto

Frans Pegt en Carola

van Wijk, Rijksmuseum,

Amsterdam 
waren uitgehakt. In het algemeen waren de achterkanten dus niet zichtbaar. In Quists ontwerp worden alle beelden vrijstaand getoond. De bezoeker kan er omheen lopen en alle kanten bekijken; soms zelfs de constructie waarmee de beelden staande gehouden worden. Het thema 'sculptuur' komt zo wel heel duidelijk tot uitdrukking.

Een twintigtal beelden uit de Scheveningse collectie worden tussen de Aziatische beelden 'gestrooid'. Er is werk van onder anderen Charlotte van Pallandt, Eja Siepman van den Berg, Tony van de Vorst, Eric Claus, Ossip Zadkine en Tajiri. Deze moderne sculpturen zijn een weergave van mensen met verschillende sociale achtergronden. Daartussen bevinden zich bekende figuren, zoals koningin Wilhelmina, prinses Maxima, Igor Strawinsky, Berthold Brecht en Johan Cruijff. Het zijn moderne, realistische portretten met wrat en al. De Aziatische beelden uit Indonesië, India, Pakistan en China uit de $3^{e}$ tot $19^{e}$ eeuw, stellen goden, goddelijke of bovennatuurlijke wezens uit het hindoeïstisch en boeddhistisch pantheon voor. Die worden volgens gangbare idealen uitgebeeld. Die hebben geen ontsierende wratten; wel schoonheidskenmerken die een bijzondere gave aanduiden. Zo hebben bijvoorbeeld boeddha's en bodhisattva's (wezens met boeddha-potentie) op hun voorhoofd iets wat veel op een wrat lijkt, een oerna. Dit is een soort moedervlek met een kruin waarvan de haartjes in een cirkel groeien. Is dit inhoudelijke, fundamentele contrast tussen beelden uit Oost en West ook zichtbaar aan de sculpturen? Het is aan de bezoeker dat te ontdekken. Maar ook zonder deze kennis blijft de vraag: hoe worden in verschillende culturen, landen, perioden en materialen koppen en lijven, al dan niet met versiering of bekleding, vormgegeven? De bezoeker wordt uitgenodigd zelf te kijken en te vergelijken. Omdat er heel wat schoons te zien is, wordt dat genieten.

'Hemelse beelden uit oost en west' is vanaf 26 februari te zien en blijft een jaar staan. Alleen het grote Zuid-Indiase bronzen beeld van de Dansende Shiva, dat een centrale plaats in de opstelling heeft, gaat eerder weg. Het wordt uitgeleend aan een tentoonstelling over de Dansende Shiva in het Rietberg Museum in Zürich. Het ligt in de bedoeling daarvoor in de plaats een kunstwerk neer te zetten dat geïnspireerd is op de Dansende Shiva.

- Museum Beelden aan Zee, Harteveltstraat 1, 2586 EL Den Haag-Scheveningen, tel. 070-3585857, maandags gesloten, museumjaarkaart niet geldig. 


$$
\frac{1}{4}
$$

